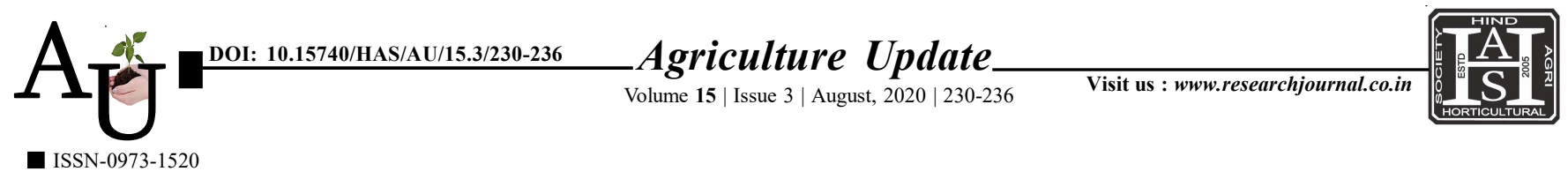

\title{
Research Article: Promising integrated farming system crops + Horticulture + Dairy + Poultry developed and demonstrated at farmer's for doubling tribal farmers income in high altitude tribal area of Andhra Pradesh
}

Article Chronicle : Received :

25.02.2020;

Revised:

18.06.2020;

Accepted :

20.07.2020

KEY WoRds: Integrated farming systems,

Diversification, Livestock, Economics , B:C ratio

Author for correspondence :

K. Tejeswara Rao All India Coordinated Research Project on Integrated Farming Sysytems (A.N.G.R.A.U.), Gajulurega, Vizianagram (A.P.) India

Email: tejaseniorscientist @gmail.com

See end of the article for authors' affiliations
SUMMARY : Farming systems approach introduces a change in farming techniques for attaining food and nutritional security and for maximizing farm income through optimal utilization of resources by a judicious mix of allied enterprises like dairy, small ruminants like goat and sheep, poultry, piggery, fishery, sericulture etc., with crops suitable for the existing agro-climatic conditions and socio-economic status of the farmers. On farm research was conducted in 36 small tribal farmers fields o in high altitude and tribal area of Srikakulam district of Andhra Pradesh state in East Coast Plain and Hills Agro-climatic zone East coast plains, hot, sub humid to semi arid eco region ( $\mathrm{S} 7 \mathrm{Cd} 2-5)$. Agro-ecological region with $915 \mathrm{~mm}$ rainfall distribution in 55 rainy days. By diversification in all enterprises farmers realized Rs. $83,630,96,830,1,04,720$ and 1,12,960 gross returns and Rs.57435, 68600, 65080 and 81240 net returns was than the bench mark Rs. 53110 and Rs. 35430 at the additional cost of interventions of Rs. 8515 than the bench mark cost of cultivation Rs. 17680 in 2012-13, 2013-14, 2014-15 and 2015-16, respectively. Net returns are getting doubled from the third year of interventions onwards. The increase income is attributed to increase in income from intervention in paddy crop and cashew crop, introduction of YMV tolerant green gram variety, feeding of supplement feed to the cattle and also the introduction of Vanaraja and Rajshri back yard poultry birds. In addition to this not only due to diversification of existing enterprises, but also introduction of Azolla and nutritional kithen garden, helped the farmer nutritional food, besides reduction in cost of maintenance helped in increase in net returns recorded. By introduction of interventions the cost of cultivation is increased by 63.73 per cent with increase of gross returns by 87.42 per cent and net returns of 99.23 per cent with 13.33 per cent increase in B:C ratio was observed. The area share was allocated 44 per cent to crops, 43 per cent horticultural crops, $1-2$ per cent area for other components, these various components the net income was maximum in livestock (44.93\%), closely followed by horticulture (37.93\%) and crops (16.14\%). Additionally 54 man days were created on an average during four years of introduction of IFS approach due to diversification of enterprises and introduction of few enterprise.

How to cite this article : Tejeswara Rao, K., Srinivasa Rao, M.M.V. and Nagarajuna, D. (2020). Promising integrated farming system crops + Horticulture+ Dairy + Poultry developed and demonstrated at farmer's for doubling tribal farmers income in high altitude tribal area of Andhra Pradesh. Agric. Update, 15(3): 230-236; DOI : 10.15740/HAS/AU/15.3/230-236. Copyright@ 2020: Hind Agri-Horticultural Society. 